\title{
Identifikasi Kutukebul (Hemiptera: Aleyrodidae) dari Beberapa Tanaman Inang dan Perkembangan Populasinya
}

\author{
YULIANI, PURNAMA HIDAYAT, DAN DEWI SARTIAMI \\ Alumnus Program S2,Program Studi Entomologi-Fitopatologi, IPB \\ Jl. Kamper, Kampus Darmaga, IPB, Bogor \\ (diterima July 2005, disetujui September 2005)
}

\begin{abstract}
Identification of whiteflies (Hemiptera: Aleyrodidae) from several host plants and their population growth. Whiteflies (Hemiptera: Aleyrodidae) can cause direct and indirect damages on plants, especially vegetables. There is only limited information regarding taxonomy and population dynamic of whiteflies attacking vegetables in Indonesia. This research is conducted to identify species of whitefly collected from chili pepper, tomato, and soybean, and to study their population dynamic. The information gathered from these studies will be useful to support whitefly management in the field. Based on morphology identification of the puparium collected directly from the host plants, there were four species of whitefly identified from chili pepper, tomato, and soybean in Bogor, Cianjur, and Sukabumi, i.e. Bemisia tabaci, Aleurodicus dispersus, Trialeurodes vaporariorum, and Dialeurodes sp. The presence of B. tabaci on chili pepper and tomato was associated with virus infection that causes yellowing and leaf curl disease. This population of B. tabaci tended to increase along with plant growth and generally reached the highest population when the plant was 60-70 days after planting.
\end{abstract}

KEY WORDS: Diversity, whiteflies, population.

\section{PENDAHULUAN}

Kutukebul (Hemiptera: Aleyrodidae) dapat menyebabkan kerusakan langsung dan tidak langsung pada tanaman. Serangan kutukebul pada tanaman menimbulkan gejala berupa bintik-bintik klorotik yang terjadi karena luka akibat stilet kutukebul yang menembus tanaman. Bintik-bintik tersebut dapat mengakibatkan berkurangnya jumlah klorofil pada daun. Gangguan terhadap pertumbuhan tanaman akan lebih berarti bila saliva kutukebul yang masuk ke dalam jaringan tanaman mengandung toksin atau virus (Pollard 1955, Kalshoven 1981). Virus yang ditularkan oleh kutukebul di antaranya adalah kelompok Geminivirus yang dapat menyerang tanaman tomat, cabai, kacangkacangan, labu, tebu, singkong, tembakau, dan jagung. Penyakit yang disebabkan oleh Geminivirus dapat mengakibatkan terhambatnya proses fotosintesis, pertumbuhan tanaman, pembentukan buah, dan menurunkan kualitas buah. Beratnya frekuensi serangan dan epidemik penyakit per tahun dapat menurunkan hasil tanaman sebesar 30- 
100\% (Agrios 1997). Kerugian akibat infeksi Geminivirus juga telah banyak dilaporkan, diantaranya African cassava mosaic virus (ACMV) yang menyebabkan kerugian hasil sebesar 70\% di Afrika. Di Negara lain, yaitu Libanon dan Jordania, kerugian akibat infeksi Geminivirus pada tanaman tomat mencapai 50-70\% (Bock et al. 1977).

Salah satu spesies kutukebul, yaitu Bemisia tabaci Genn., merupakan hama yang dalam beberapa tahun terakhir ini populasinya meningkat dan menyerang tanaman kedelai di berbagai daerah di Indonesia. Serangan pertama dilaporkan di Indramayu pada tahun 1980 dengan luas serangan sekitar 30-50 ha. Tahun berikutnya terjadi serangan pada pertanaman kedelai dan kacang hijau di Cirebon seluas 300 ha. Pada bulan Februari dan Maret tahun 1982, serangan meluas di daerah Lampung Tengah dengan luas serangan sekitar 100 ha. Dilaporkan juga pada musim tanam 1983/1984, hama ini menyerang pertanaman kedelai di Purworejo dan Wonosari (Yogyakarta) (Saranga, 1985).

Di Sulawesi Utara, khususnya Manado, Minahasa, dan sekitarnya, pernah dilaporkan terjadi ledakan populasi salah satu spesies Aleyrodidae. Ledakan populasi kutukebul tersebut cukup menimbulkan masalah bagi petani karena spesies ini memiliki kisaran tanaman inang yang luas dan biasanya menyebabkan kematian pada tanaman yang sudah terserang berat. Maramis (1991) menyatakan bahwa spesies yang menyerang tersebut adalah Aleurodicus dispersus Russel.

Kegagalan tindakan pengendalian serangan hama dapat disebabkan karena adanya kesalahan dalam identifikasi dan penentuan nama ilmiah suatu spesies (Watson 1997). Informasi mengenai keanekaragaman spesies kutukebul, ekologi, luas dan intensitas serangannya masih belum lengkap. Oleh karena itu, perlu dilakukan penelitian untuk mengidentifikasi spesies kutukebul, serta mengetahui kisaran inang dan tingkat populasinya, sehingga diperoleh informasi yang dapat menunjang keberhasilan tindakan pengendalian.

Penelitian ini bertujuan untuk mengidentifikasi spesies kutukebul pada tanaman cabai, tomat, dan kedelai, serta mengamati tingkat populasi kutukebul pada pertanaman cabai dan tomat di Bogor, Cianjur, dan Sukabumi.

\section{BAHAN DAN METODE}

\section{Pengumpulan Kutukebul}

Kantung pupa kutukebul yang masih melekat pada jaringan daun dikumpulkan dari pertanaman tomat (Lycopersicon esculentum Mill.), cabai (Capsicum annuum L.), dan kedelai (Glycine soya Max.) di Bogor, Cianjur, dan Sukabumi. Sampel puparium tersebut dibawa ke Laboratorium Biosistematika Serangga, Departemen Proteksi Tanaman, IPB. Dengan bantuan mikroskop, puparium dilepaskan secara perlahanlahan dari jaringan daun menggunakan jarum bertangkai yang tipis. Selanjutnya 
puparium disimpan di dalam alkohol $70 \%$ hingga siap untuk diawetkan dalam bentuk preparat mikroskop.

\section{Pembuatan Preparat Mikroskop dan Identifikasi Kutukebul}

Kantung pupa hasil koleksi di pindahkan ke dalam alkohol $80 \%$ selama 10 menit yang ditempatkan pada gelas arloji, lalu dipindahkan secara hati-hati ke dalam tabung reaksi yang berisi larutan $\mathrm{KOH} 10 \%$, kemudian dipanaskan selama 5-10 menit (sampai puparium menjadi transparan). Setelah dilakukan pencucian dengan akuades sebanyak 2 kali, puparium kemudian dimasukkan ke dalam alkohol 50\% selama 10 menit, di tambahkan 3 tetes asam fuchsin selama 20 menit, dan ditambah lagi dengan 1 tetes asam asetat glasial, dan didiamkan selama \pm 10 menit. Puparium dimasukkan ke dalam alkohol 80\% selama 5-10 menit, kemudian dipindahkan ke dalam alkohol absolut selama 10 menit, dan setelah itu dimasukkan ke dalam asam asetat glasial selama 10 menit, selanjutnya dalam alkohol absolut selama 5-10 menit, dimasukkan ke dalam carbol xylene selama 1 menit, dan dimasukkan lagi dalam alkohol absolut selama 5-10 menit. Puparium direndam di dalam minyak cengkeh selama 10 menit, dan ditempatkan pada gelas objek dengan menambahkan canada balsam, lalu ditutup dengan cover glass. Preparat mikroskop yang telah jadi dikeringkan di atas pemanas. Identifikasi kutukebul dilakukan dengan menggunakan bantuan mikroskop dan kunci identifikasi kutukebul (Martin 1987; Martin et al. 2000).

\section{Penghitungan Populasi Kutukebul}

Penghitungan dilakukan dengan cara mengambil tanaman contoh dari seluruh populasi tanaman dalam satu petak. Tanaman contoh ditentukan dengan menggunakan metode sistematik dua dimensi seperti pada Gambar 1 (Untung 1993). Jumlah populasi kutukebul pada setiap tanaman contoh dicatat, lalu dihitung rata-rata populasinya.

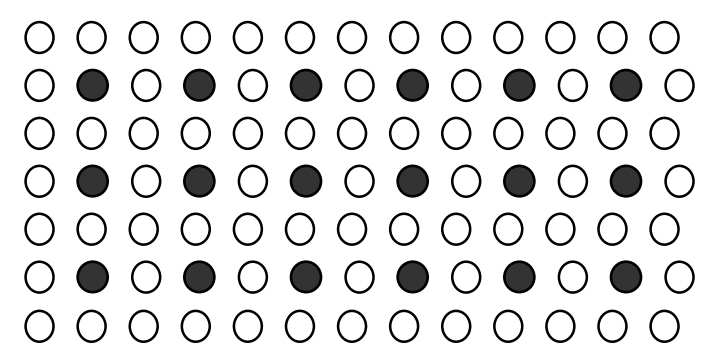

Gambar 1. Pengambilan sampel puparium kutukebul pada tanaman contoh $(\mathrm{O})$ dengan metode sistematik dua dimensi. 


\section{HASIL DAN PEMBAHASAN}

\section{Keanekaragaman Spesies Kutukebul}

Berdasarkan hasil identifikasi kantung pupa dapat diketahui adanya empat spesies kutukebul yang menyerang tanaman tomat, cabai, dan kedelai di daerah Bogor, Cianjur, dan Sukabumi. Spesies kutukebul tersebut adalah Bemisia tabaci, Aleurodicus dispersus, Trialeurodes vaporariorum, dan Dialeurodes sp. (Tabel 1).

\section{Ciri-Ciri B. tabaci}

Subdorsum tanpa pori majemuk. Lingula sangat bervariasi, namun ukurannya tidak besar dan berbentuk lidah. Apabila terlihat, tidak terdapat 4 pasang rambut yang jelas. Pupa tidak terlalu memanjang, jarang yang lebih dari 1,65 kali lebarnya. Permukaan dorsal tanpa pola duri yang kokoh. Lebih dari setengah vasiform orifice hanya ditempati oleh operculum atau oleh operculum bersama dengan kepala lingula. Vasiform

Tabel 1. Spesies-spesies kutu kebul, tanaman inang, dan kisaran lokasi

\begin{tabular}{llll}
\hline \hline Spesies kutukebul & Tanaman inang & Lokasi Penyebaran & Tanggal koleksi \\
\hline Bemisia tabaci & Kedelai & Ciapus, Bogor & $15-02-01$ \\
& & Cimanggu, Bogor & $21-03-01$ \\
& Cabai & Citayam, Bogor & $20-07-01$ \\
& & Citayam, Bogor & $05-10-00$ \\
& Tomat & Cugenang, Cianjur & $09-08-01$ \\
& & Golpara, Sukabumi & $30-08-01$ \\
Trialeurodes & & Cibeureum, Bogor & $05-05-01$ \\
vaporariorum & Tomat & Cibodas, Cianjur & $15-06-01$ \\
& & Sukaraja, Sukabumi & $22-09-00$ \\
Dialeurodes sp & & Saungmirwan, Cianjur & $28-06-01$ \\
Aleurodicus dispersus & Tomat & Pasir Sarongge, Cianjur & $09-08-01$ \\
\hline
\end{tabular}

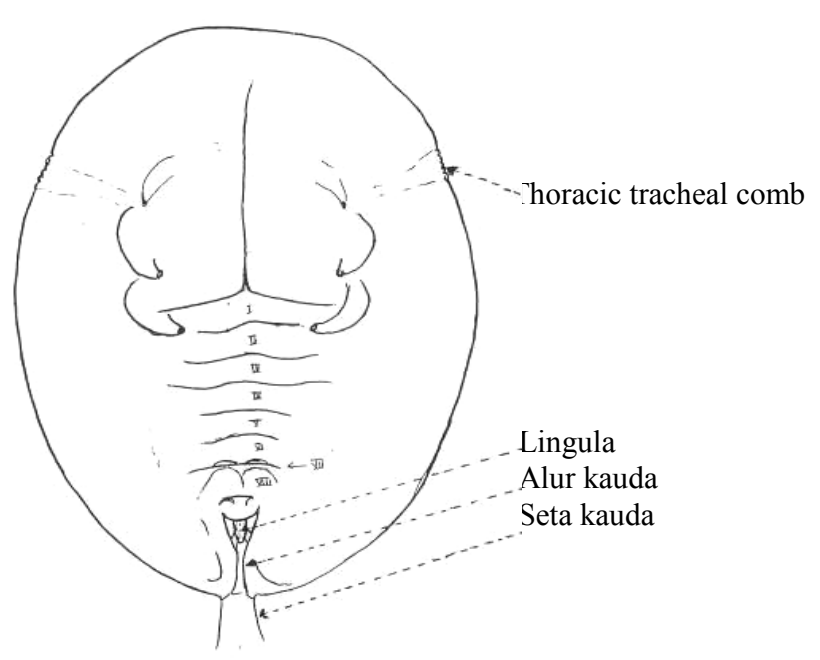

Gambar 2. Kantung pupa B. tabaci 
orifice seringkali terdapat di pinggir posterior dari kantung pupa dengan jarak yang sama dengan panjang vasiform orifice (Gambar 2).

Pada submargin tidak ada atau hampir tidak ada deret papila. Kepala lingula tidak lobular. Kutikula kantung pupa berwarna pucat, kadang-kadang dengan tanda kecoklatan yang terlokalisasi. Bukaan trakea torak dan kauda pada bagian pinggir ada yang ditandai dengan sisir yang terdiri dari gigi-gigi yang jelas (Gambar 2). Sebagian dari permukaan diskus dorsal atau area sub median memiliki batasan, tetapi bukan berupa lipatan menyerupai jahitan.

Ruas VII abdomen sering tertutup oleh kantung-kantung, sehingga hanya 7 ruas yang terlihat (Gambar 2). Vasiform orifice berbentuk segitiga, lebih panjang dari lebar dasarnya, sisinya lurus atau konkaf. Mempunyai alur kauda (caudal furrow) yang terlihat jelas. Seta kauda selalu kokoh, biasanya sama panjang dengan vasiform orifice. Vasiform orifice terdapat pada bagian tepi kantung pupa dengan jarak lebih pendek daripada panjang vasiform orifice (panjang vasiform orifice $>$ panjang alur kauda) (Gambar 2).

\section{Ciri-ciri A. dispersus}

Subdorsum memiliki pori majemuk penghasil lilin, satu pasang pada daerah kepala, dan empat pasang pada bagian abdomen. Lingula berukuran besar, berbentuk lidah yang memanjang melebihi bagian tepi posterior vasiform orifice (Gambar 3). Lingula memiliki empat setae yang biasanya terlihat jelas, tetapi kadang-kadang ada dua atau lebih setae yang tereduksi. Pupa sering ditutupi oleh sekresi kelenjar lilin yang kusut.

Pori majemuk semuanya berukuran sama, diameternya lebih dari 28 $\mu \mathrm{m}$, yang terdapat pada bagian abdomen segmen III-VI (Gambar 3). Diskus dorsal dengan pori-pori septat yang jelas terdapat di daerah submedian, dan sebagian besar dengan pori-pori rimmed

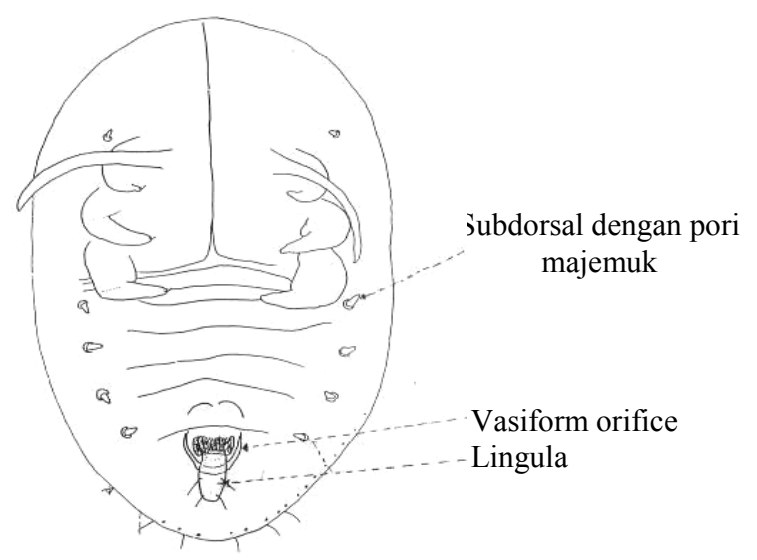

Gambar 3. Kantung pupa A. dispersus (skala $1: 200$ ) 
yang luas dan padat terdapat di daerah subdorsal.

\section{Ciri-ciri $T$. vaporariorum}

Subdorsum tidak memiliki pori majemuk. Pada bagian submargin umumnya terdapat deret papila yang jelas (Gambar 4). Pupa bentuknya tidak terlalu memanjang, tetapi jarang yang lebih dari 1,65 kali lebarnya. Permukaan dorsal tanpa pola duri yang kokoh. Lebih dari setengah vasiform orifice hanya ditempati oleh operculum atau operculum bersama dengan kepala lingula. Lingula sangat bervariasi, namun ukurannya tidak terlalu besar. Apabila terlihat, biasanya tidak memiliki empat pasang rambut yang jelas. Kepala lingula berbentuk lobular (Gambar 4), walaupun kadang-

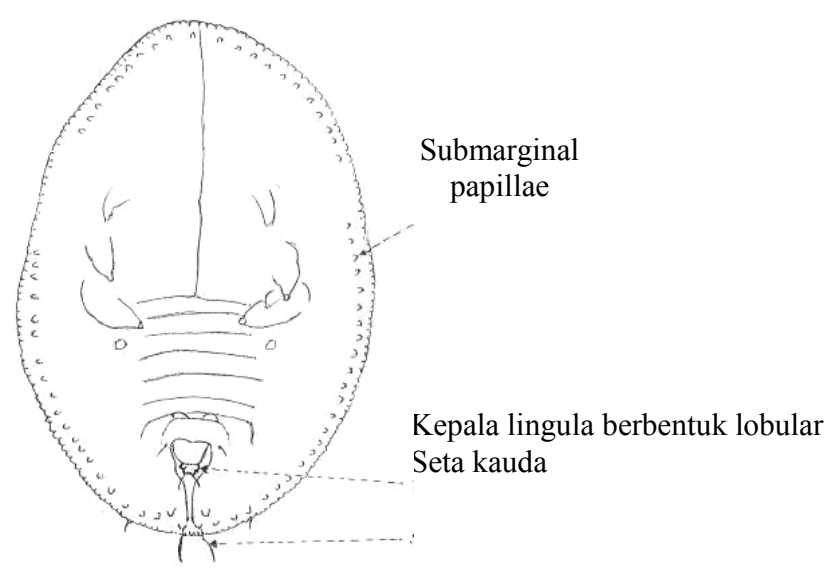

Gambar 4. Kantung pupa T. vaporariorum (skala $1: 200$ )

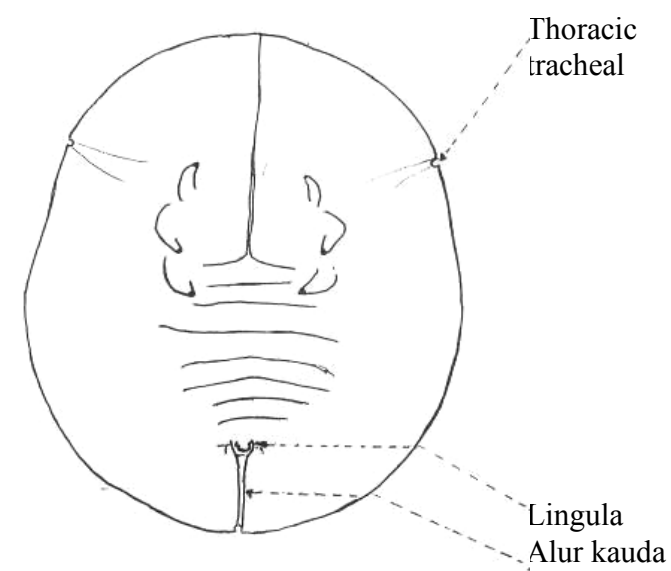

Gambar 5. Kantung pupa Dialeurodes sp. (skala $1: 200$ ) 
kadang terhalang oleh operculum sehingga sulit untuk dilihat. Pada dasar kepala lingula terdapat sepasang cuping yang ditutupi oleh operculum.

Kantung pupa berwarna pucat, kadang-kadang dengan tanda kehitaman. Pada bagian pinggir bukaan trakea torak dan kauda kadang-kadang terdapat semacam sisir yang terdiri dari gigi-gigi tumpul (Gambar 4). Di bagian submargin, selalu ada papila yang ukurannya setara. Bagian dasar tungkai tengah dan belakang biasanya memiliki duri yang jelas. Papila di bagian submargin tidak terlalu rapat, kurang tajam, dan agak membulat (Gambar 4). Subdorsal kadang-kadang memiliki beberapa papila yang berukuran lebih besar. Pada bagian dasar tungkai tengah dan belakang terdapat seta yang kecil dan halus dengan panjang $8 \mu \mathrm{m}$.

\section{Ciri-ciri Dialeurodes sp.}

Subdorsum tidak memiliki pori majemuk. Bentuk pupa tidak terlalu memanjang (Gambar 5), jarang yang lebih dari 1,65 kali lebarnya. Permukaan dorsal tidak memiliki pola duri yang kokoh. Lebih dari setengah vasiform orifice hanya ditempati oleh operculum. Submargin tanpa deret rambut atau duri yang teratur. Pada bagian submargin tidak ada deret papila. Kepala lingula, tidak lobular. Kantung pupa berwarna pucat.

Pada bagian bukaan trakea torak dan kauda terdapat lekukan pori-pori yang bagian dalamnya mungkin halus atau bergerigi (Gambar 5). Bagian dalam pori-pori trakea torak agak halus. Sutura longitudinal dan sutura ganti kulit tidak menyatu. Sutura longitudinal meluas sampai ke bagian pinggir kantung pupa, sedangkan sutura transverse tidak. Sutura ganti kulit kadang-kadang tidak terlihat jelas.

\section{Tingkat Populasi B. tabaci}

Dari hasil pengamatan pada enam lokasi diketahui bahwa tingkat populasi B. tabaci pada pertanaman cabai dan tomat mengalami perubahan sesuai dengan fase pertumbuhan tanaman inangnya (Gambar 6 dan 7). Pada fase awal pertumbuhan tanaman, populasi kutukebul sangat sedikit. Namun, makin tua umur tanaman, populasi B. tabaci makin meningkat dan mencapai puncaknya pada saat tanaman berumur 63-77 hari setelah tanam. Selanjutnya, populasi kutukebul tersebut akan menurun kembali.

Rata-rata populasi kutukebul tertinggi terdapat pada pertanaman cabai di lokasi I (Citayam, Bogor). Tingginya populasi tersebut dipengaruhi secara langsung maupun tidak langsung oleh lingkungan. Menurut Lanya (1988), hujan adalah unsur iklim dan cuaca yang berpengaruh terhadap kelangsungan hidup kutukebul ini. Curah hujan yang tinggi dapat meningkatkan mortalitas imago. Berkurangnya curah hujan hingga taraf tertentu dapat memberi peluang bagi pertumbuhan dan perkembangan kutukebul. 
Setelah mencapai puncak populasi pada saat tanaman berumur 63-77 hari, umumnya populasi B. tabaci mulai menurun (Gambar 6 dan 7). Menurut Lanya (1988), setelah tanaman berumur 45 hari, kepadatan populasi telur, nimfa, dan puparium mulai menurun. Tanaman pada umur tersebut kurang sesuai atau tidak disukai lagi sebagai makanan dan sebagai tempat peletakan telur oleh imago kutukebul karena relung ekologisnya yang berupa daun-daun muda sudah tidak ada, atau dengan kata lain pertumbuhan vegetatif tanaman sudah berhenti.

\section{KESIMPULAN}

Berdasarkan ciri morfologi kantung pupa dapat diketahui empat spesies kutukebul yang menyerang tanaman cabai, tomat, dan kedelai di Bogor,

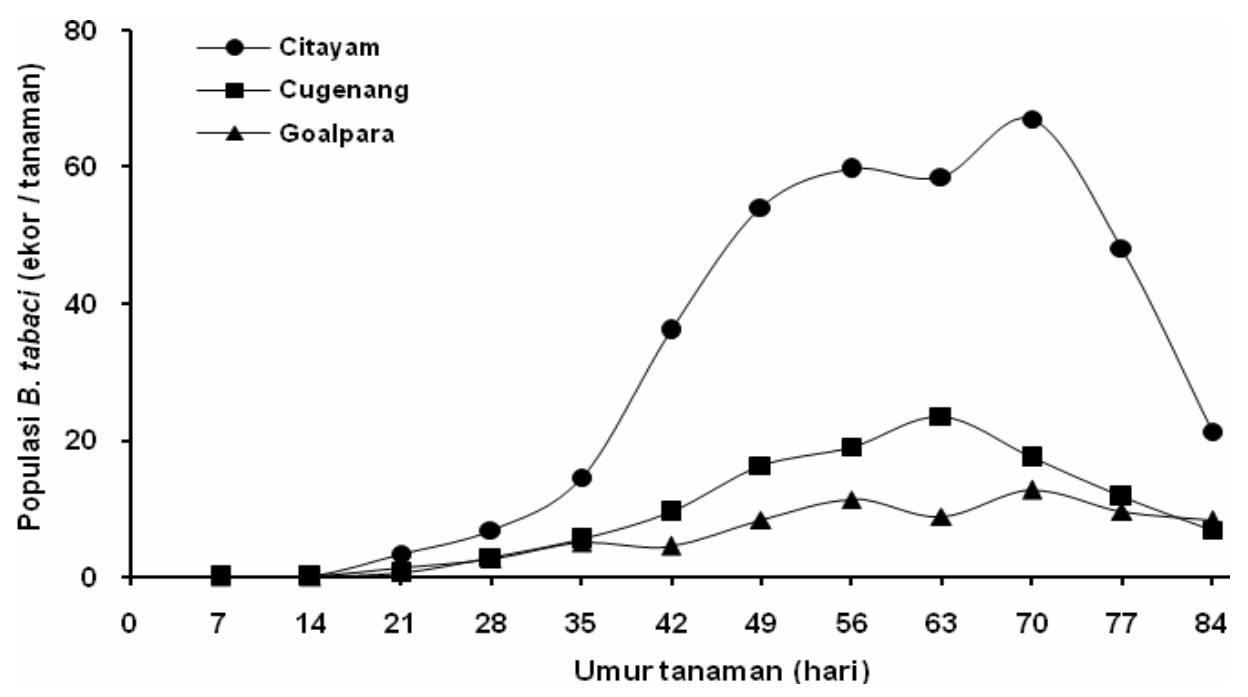

Gambar 6. Rata-rata populasi B. tabaci pada beberapa lokasi di pertanaman cabai

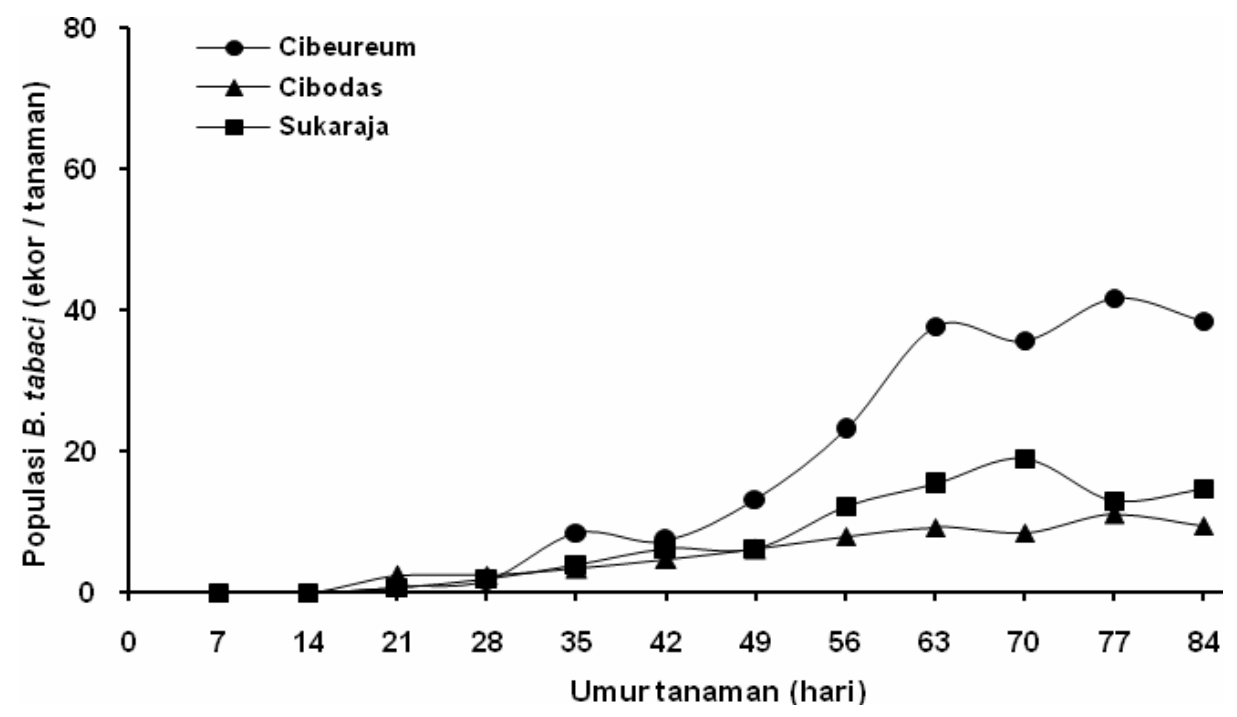

Gambar 7. Kantung pupa Dialeurodes sp. (skala $1: 200$ ) 
Cianjur, dan Sukabumi; yaitu Bemisia tabaci, Aleurodicus dispersus, Trialeurodes vaporariorum, dan Dialeurodes sp.

Secara umum tingkat populasi $B$. tabaci masih rendah pada fase awal pertumbuhan tanaman. Puncak populasi B. tabaci terjadi pada saat tanaman berumur 60-70 hari setelah tanam (HST). Semakin tua umur tanaman, populasi kutukebul cenderung menurun.

\section{DAFTAR PUSTAKA}

Agrios GN. 1997. Plant Pathology. San Diego: California Acad. Press. 551p.

Bock KR, EJ Gutric, G Meredeth, H Baker. 1977. RNA and Protein Component of Maize Sterak Virus and Cassavaleafvirus. Ann. Appl. Biol. 85: 305-308.

Kalshoven LGE. 1981. The Pests of Crops in Indonesia. Revised and translated by P.A. Van der Laan. Jakarta: PT. Ikhtiar Baru Van Hoeve.

Lanya H. 1988. Pengaruh waktu tanam, varietas, pemupukan, dan jarak tanam kedelai terhadap pertumbuhan populasi B. tabaci Genn. [Tesis]. Bogor: Program Pascasarjana Institut Pertanian Bogor.
Martin JH. 1987. An Identification Guide to Common Whitefly Pest Species of the World (Homoptera: Aleyrodidae). Tropical Pest Management 33 (4): 298-322.

Martin JH, D Mifsud, C Rapisarda. 2000. The Whiteflies (Hemiptera: Aleyrodidae) of Europe and the Mediteranean Basin. Bull. Entomol. Res. 90: 407-448.

Maramis, Redsway T.D. 1991. Bionomi Aleurodicus dispersus Russell (Homoptera: Aleyrodidae) pada tanaman cabai, kacang hijau, dan jambu biji. [Tesis]. Bogor: Program Pascasarjana Institut Pertanian Bogor.

Pollard DG. 1995. Feeding Habits of the Cotton Whitefly, Bemisia tabaci Genn. (Hemiptera: Aleyrodidae). Ann. Appl. Biol. 43 (4): 664671.

Saranga AP. 1985. Pengaruh varietas dan umur kedelai terhadap pola perilaku dan pertumbuhan populasi Bemisia tabaci Genn. (Homoptera: Aleyrodidae). [Tesis]. Bogor: Program Pascasarjana Institut Pertanian Bogor.

Untung K. 1993. Pengantar Pengelolaan Hama Terpadu. Yogyakarta: Gadjah Mada University Press.

Watson GW. 1997. The Role of Taxonomy in Biological Control, With Special Reference to Insects. Makalah kongres $\mathrm{V}$ dan simposium Perhimpunan Entomologi Indonesia di Universitas Padjajaran 24-26 Juni 1997. Bandung. 